1957

\title{
Metabolic activity of protein amide groups
}

Donald Dudley Clarke PhD

Fordham University, clarke@fordham.edu

Amos Neidle

Nirmal K. Sarkar

Heinrich Waelsch

New York Psychiatric Institute

Follow this and additional works at: https://fordham.bepress.com/chem_facultypubs

Part of the Biochemistry Commons

\section{Recommended Citation}

Clarke, Donald Dudley PhD; Neidle, Amos; Sarkar, Nirmal K.; and Waelsch, Heinrich, "Metabolic activity of protein amide groups" (1957). Chemistry Faculty Publications. 80.

https://fordham.bepress.com/chem_facultypubs/80

This Article is brought to you for free and open access by the Chemistry at DigitalResearch@Fordham. It has been accepted for inclusion in Chemistry Faculty Publications by an authorized administrator of DigitalResearch@Fordham. For more information, please contact considine@fordham.edu. 
Reprinted from Archrves of Blochemristry AND Biophysics, Volume 71, No. 1, September, 1957 Academic Press Inc.

\section{Metabolic Activity of Protein Amide Groups}

Recently an enzymically catalyzed, $\mathrm{Ca}^{++}$-activated incorporation of aliphatic amines, such as cadaverine or ethanolamine, into a protein fraction of liver, kidney, and brain was described (1). To the list of amines acting as substrates for incorporation may now be added putrescine, spermine, and histamine which were tested as $\mathrm{C}^{14}$-labeled compounds. The incorporation of spermine and putrescine suggests an explanation for the inhibition of cadaverine incorporation by these amines reported previously. In addition it was shown that ammonia acted as an inhibitor of eadaverine incorporation (1). Therefore, the incorporation of $\mathrm{N}^{15}$ ammonia into the protein fraction active in amine fixation was tested. A purified protein fraction (1) of guinea pig liver (105 mg.) was incubated with $\mathrm{N}^{15} \mathrm{H}_{4} \mathrm{NO}_{3}$ $\left(80 \mu \mathrm{M} ; 60\right.$ atom \% excess $\left.\mathrm{N}^{15}\right)$ in a total volume of $8 \mathrm{ml}$. of $0.04 M$ barbital buffer, $\mathrm{pH} 8.2$, in the absence (A) and presence (B) of $160 \mu \mathrm{M} \mathrm{Ca}^{++}$at $37^{\circ} \mathrm{C}$. for $30 \mathrm{~min}$. The incubation mixtures were dialyzed against a large volume of $0.01 M$ phos-

${ }^{1}$ This work was supported by grants from the National Institute of Neurological Diseases and Blindness (Grant B-226) and from the Ford Foundation and by a contract between the Office of Naval Research and the Psychiatric Institute. 
phate buffer, $\mathrm{pH} 7.6$, for $14 \mathrm{hr}$. (two changes). The protein was precipitated with $\mathrm{HClO}_{4}$, washed (2), hydrolyzed in $6 \mathrm{~N} \mathrm{HCl}$, the hydrolyzate made alkaline, $\mathrm{NH}_{3}$ collected and analyzed for $\mathrm{N}^{15}$ concentration. A: 0.0 ; B: 2.1 atom $\%$ excess $\mathrm{N}^{15}$. It is assumed that the ammonia obtained corresponds mainly to the amide groups of the protein. The results suggest that amines as well as ammonia are incorporated by replacement of amide groups of the protein, a mechanism already proposed for the $\mathrm{Ca}^{++}$-activated incorporation of lysine into protein (3). The extent of the above-found incorporation of $\mathrm{N}^{15} \mathrm{H}_{3}$ into protein would correspond to a net replacement of $3 \%$ of the amide groups.

During the course of this study it was observed that the protein fraction active in amine incorporation was inactivated very easily, particularly when incubated in the presence of $\mathrm{Ca}^{++}$. It could be shown that during this inactivation considerably greater amounts of ammonia were liberated in the presence than in the absence of $\mathrm{Ca}^{++}$(Table I). The $\mathrm{Ca}^{++}$-activated liberation of ammonia exceeded considerably the estimated amount of amide groups replaced by $\mathrm{C}^{14}$ labeled amines or $\mathrm{N}^{15}$ ammonia. The ammonia liberation was activated by $\mathrm{Ca}^{++}$ but not by $\mathrm{Mg}^{++}, \mathrm{Sr}^{++}$, or $\mathrm{Ba}^{++}$, nor was it shown by another protein fraction from liver inactive in amine incorporation. At present the fraction of the ammonia derived from sources other than the amide groups of protein has not been established (5). The possibility is now under investigation that the liberation of ammonia in the presence of $\mathrm{Ca}^{++}$is not solely hydrolytic but may be an exchange of the amide group with the $\epsilon$-amino group of protein-bound lysine with liberation of amide ammonia. This possibility is supported by a study of $\mathrm{Ca}^{++}$-inactivated protein from which, after exhaustive deamination with nitrous acid, small amounts of intact lysine could be isolated.

In summary, these experiments point to the occurrence in liver and other organs of a protein fraction with metabolically labile amide groups. Whether

TABLE I

Ammonia Liberation by Protein Fraction of Liver

\begin{tabular}{llll}
\multicolumn{5}{c}{ Ammonia Liberation by Protein Fraction of Liver } \\
$\mu \mathrm{M} \mathrm{NH}_{3}$ liberated per \\
$-\mathrm{Ca}^{++}$ & $\begin{array}{c}100 \mathrm{mg} \text {. protein } \\
+\mathrm{Ca}^{++}(80 \mu \mathrm{M})\end{array}$ \\
1 & $\mathrm{P}$ & 3 & 8.6 \\
2 & $\mathrm{P}$ + cadaverine $(16 \mu \mathrm{M})$ & 2.8 & 8.4 \\
3 & $\mathrm{P}+$ cadaverine $(16 \mu \mathrm{M})^{*}$ & & 1.1 \\
4 & $\mathrm{P}+\mathrm{Sr}(\mathrm{Ba}$ or $\mathrm{Mg})(80 \mu \mathrm{M})$ & $0.7-3.1$ & \\
5 & $\mathrm{P}^{\prime}$ & & 0.4
\end{tabular}

P partially purified fraction (obtained at 18 to $26 \%$ ammonium sulfate saturation of $100,000 \times g$ supernatant fluid of guinea pig liver homogenates in $0.25 \mathrm{M}$ sucrose solution) which incorporated $800 \mathrm{cts} . / \mathrm{min}$./infinite thickness of $\mathrm{C}^{14}$ cadaverine (1). This corresponds to $2.3 \mu \mathrm{M}$ cadaverine incorporation per $100 \mathrm{mg}$. protein. Total volume of $4 \mathrm{ml}$. of $0.04 M$ barbital buffer containing $100 \mathrm{mg}$. P, incubated at $37^{\circ} \mathrm{C}$. for $60 \mathrm{~min}$.

* Experiment 3: reaction stopped at 0 time. $\mathrm{P}^{\prime}$ protein fraction inactive in cadaverine incorporation obtained from liver homogenate at 25 to $45 \%$ ammonium sulfate saturation. Reactions stopped by addition of $\mathrm{HClO}_{4} ; \mathrm{NH}_{3}$ determined according to (4). 
substrate and enzyme protein are two different entities cannot be stated at present. The activity of the amide groups in amine incorporation may be of considerable biological significance as pointed out previously (1), not only as concerns the fixation and metabolism of biologically important amines but also because of the possibility of the formation of modified proteins. The $\mathrm{Ca}^{++}$-activated liberation of ammonia from proteins supports the recent claim that some unassigned tissue ammonia originates in the amide groups of proteins (6). The biological significance of a change of properties of tissue proteins by loss of the amide group cannot be assessed at present. A possible involvement of the $\epsilon$-amino group of protein-bound lysine in the mechanism of amide-ammonia liberation is of particular interest since an analysis of collagen (7) appears to indicate the natural occurrence of lysine substituted in this amino group.

\section{References}

1. Sarkar, N. K., Clarke, D. D., and Waelsch, H., Biochim. et Biophys. Acta in press.

2. Siekevitz, P., J. Biol. Chem. 195, 549 (1952).

3. Schweet, R., Federation Proc. 15, 350 (1956).

4. Sobel, A. E., Mayer, A. M., and Gottrfried, S. P., J. Biol. Chem. 156, 355 (1944).

5. Greenstein, J. P., Carter, C. E., and Chalkley, H. W., Arch. Biochem. 11, 307 (1944).

6. VRBA, R., J. Neurochem. 1, 12 (1956).

7. Bowes, J. H., And Moss, J. A., Biochem. J. 55, 735 (1953).

Department of Biochemistry,

College of Physicians and Surgeons, Columbia University and

The New York State Psychiatric Institute,

New York, New York

Received July 25,1957
Donald D. Clarke

Amos Neidle

Nirmal K. Sarkar

HEINRICH WAELSCH 